\title{
Deterioration of a Building through Environmental and Anthropological Causes
}

\author{
Kirti Chandra D., D. V. K. Sudhakar
}

\begin{abstract}
The aim of the construction of a building is to provide a secure and private space for a number of activities which would span a long period of time. During the life cycle of the building, regular maintenance by the users will ensure its proper functioning. However, its life span decreases with respect to time and usage, thereby leading to the deterioration of the building. The deterioration of a building can also be caused due to lack of proper maintenance and the absence of maintenance practices in a building thereby decreasing its life span than its optimum time period. Such non-maintained buildings tend to be vulnerable to various internal and external factors thereby developing a number of defects in each of their materials and structure. This paper focuses on the study of building defects to specify the importance of building maintenance. It is carried out by the study of an old abandoned building by the identification of defects in its current state through observation and the study of various factors and reasons that led to its deterioration. This study will be applicable to understand the importance of a building maintenance that is to be carried out together by the occupants, in identifying the maintenance practices to prevent or protect the building against similar defects and for the proposal of repair strategies required to restore any building to a functioning state in case similar defects are caused.
\end{abstract}

Keywords: Design, building construction, building materials, maintenance, defects, deterioration, damage

\section{I.INTRODUCTION}

An urban area consists of various typologies of buildings depending on its functional requirement. At a given point of time, there are many buildings which are simultaneously constructed in various parts of the city. The requirements, design, scale and time of construction may vary but the overall process of construction remains almost the same in all cases for a particular region. The construction is said to be complete when the occupants move into the building and use it in a way it is designed for. The occupants should utilize the building to its optimum capacity and also preserve its resources for as long as possible. Hence, they are responsible for the use and maintenance of their building. Defects are some of the common problems observed in buildings. They are more often seen in old building structures.

Revised Manuscript Received on February 05, 2020.

* Correspondence Author

Kirti Chandra D.*, Department of Architecture, Andhra University College of Engineering (AUCE), Visakhapatnam, Andhra Pradesh, India.

Architect, DE - AR (Designers and Architects), Visakhapatnam, Andhra Pradesh, India. E-mail: earckit.in@gmail.com

D. V. K. Sudhakar, Professor (Design chair), School of Architecture, GITAM (Deemed to be University), Visakhapatnam , Andhra Pradesh India. Email: sudhakaravk.devaguptapu@gitam.edu

Architect, DE - AR (Designers and Architects), Visakhapatnam, Andhra Pradesh, India. E-mail: sudhakardvk1960@gmail.com

(c) The Authors. Published by Blue Eyes Intelligence Engineering and Sciences Publication (BEIESP). This is an open access article under the CC BY-NC-ND license (http://creativecommons.org/licenses/by-nc-nd/4.0/)

The defects in a building may be seen at some point during their life span but can be avoided for long when its maintenance is regularly carried out by the occupants. The construction of building converts an empty site into a functional occupied building through various stages and the involvement of many people. They are explained in detail as follows:

\section{II.THE CYCLE OF BUILDING CONSTRUCTION}

\section{A. Introduction:}

The construction process involves a team on site who would ensure the completion of work within a given span of time. The entire process takes place in three different phases involving a series of steps from commencement of construction project, its execution and occupation of a building which are explained in the following sections.

\section{B. Pre-construction phase:}

This phase includes the visit of a client to an architect's office, initiation of discussion between the client and the architect about the requirement of the project, proposal of the project requirement and presentation of site details by the client (client requirement), a detailed inspection and survey of site by the architect (site analysis), preparation of design brief by the architect based on the site analysis and the client's requirement (design brief), proposal of a few design options based on different concepts by the architect (concept and design development), preparation of presentation drawings, virtual 3d models, rendered views by the architect team, preparation of a rough budget estimate for all the design options by the architect (presentation, 3d and reports), discussion between the client and the architect about the presented design options (client meetings), implementation of changes, updates and modifications in the design options as a result of client meetings, finalization of design by the client that is to be executed on site (design finalization). The involvement of an architect's perspective in site selection results in a more efficient design output for an ideal location which isn't followed very frequently. Presentation drawings are the ones that act as a medium to convey design ideas, concepts, outputs and virtually created environments among the architect, client and a concerned third party [1].

\section{Construction phase:}

The $2^{\text {nd }}$ phase of a construction project includes preparation of a set of drawings for construction approval (approval drawings) by the architect, preparation of a set of drawings for the execution of on-site construction work (working drawings) by the architect, proposal of quotations by the contractors (calling for tenders) based on the bill of quantities prepared by the architect, signing of the contractor (award of contract) based on proper quotation, execution of construction work on-site based on the working drawings prepared by the architect, regular inspection of 


\section{Deterioration of a Building through Environmental and Anthropological Causes}

construction work by the architect.

The approval drawings include site details, estimation details, floor plans, elevations, sections, terrace plan, site plan, location details, foundation details, water tank details, which are drafted with respect to the local byelaws. The working drawings or details include bill of quantities, detailed estimate, scaled architectural drawings such as floor plans, elevations, sections, masonry drawings, schedule of openings flooring details, civil and structural drawings such as beam details, slab details, lintel details, foundation details, column layout, staircase details, service drawings such as plumbing, water supply, sanitation, electrical layout, fixtures, HVAC, with required dimensions, specifications wherever required [2]. The contractor allots all the required labour workers, contracts, sub - contracts, which include site excavators, rod benders, masons, electrical and plumbing workers, carpenters etc.

\section{Post construction phase:}

The final phase of construction includes occupation of the building by the people, functioning and usage of the building by the occupants, preparation of maintenance strategies by the occupants and implementation of the maintenance practices at regular intervals for proper functioning. The life cycle of the building continues up to a certain time during which its usage and maintenance go hand in hand, after which its functionality is lost and eventually the building has to be terminated or deteriorated. A post occupancy survey, which is the process of evaluating buildings in a systematic and rigorous manner through a detailed feedback from the occupants via interviews, questionnaires ,accounts for the progress of the building functioning conducted by architects and building professionals [3].

\section{III.DEFECTS, DETERIORATION AND MAINTENANCE}

\section{A. Defects and deterioration:}

Defects represent lack of appropriate functional service which occur due to negligence and lack of appropriate knowledge during construction and management [4]. Defects can be approached in two ways namely elemental, meaning a problem in a specific component of a building or characteristic performance, meaning a problem caused in a building due to an external parameter [4]. Defects can be found in basement, foundations, damp proof courses, walls, wall finishes, chimneys, columns, beams, floors, joinery, services, ceiling, roofs, etc. [4]. Deterioration is a condition in which a building structure or its component has degenerated or become unstable [4]. The process of deterioration includes mechanical (wear and tear, fatigue, impact or overloading), physical (thermal change, volume change, cracking, deformation of shape, freezing and thawing), chemical (electro chemical processes like corrosion), and biological (bacteriological growth) [4].

\section{B. Causes:}

The factors responsible for the deterioration of a material include human aspects (lack of maintenance staff, misuse of the building), chemical factors (corrosion), environmental aspects (solar radiation, temperature effects, humidity, moisture, biological agents, solid liquid or gaseous air pollutants, ground salts and waters), external forces (wind movements, earthquakes, cyclones) [4].

\section{Introduction to maintenance:}

Maintenance is derived from a French verb "Maintenir", which connotes to hold. Building maintenance can be defined as the strategies used to maintain a building in its serviceable condition [4]. According to Mr. White, an eminent engineer, "Maintenance is synonyms with controlling the condition of a building includes services so that the serviceability remains within specific region of acceptability [4]". Regular maintenance of a building ensures avoiding the need for repair or replacement of a building component for as long as possible [4].

\section{Objectives of maintenance:}

Building maintenance aims at good serviceable condition of buildings, restoration of buildings to their original standards, implementation of improvements when required, prevention of rate of deterioration and avoid crisis due to unplanned maintenance [4].

\section{E. Methods of maintenance:}

The two common methods in maintenance are as follows [4]:

\section{Corrective maintenance:}

It involves repair and rehabilitation of a component when it fails with no prior warning until failure thereby becoming a matter of urgency [4].

Example: corrosion, repair of cracks [4].

\section{Preventive maintenance:}

It involves intervening in the life cycle of each component immediately before it is expected to fail in its service, thereby restoring it to an acceptable standard of condition [4].

Example: protective coatings, water proofing membranes [4].

\section{F. Significance of maintenance:}

Mr. Adam Neville in his key note on Maintenance and Durability of Concrete Structure said "In order to ensure durability it is not enough to make durable concrete, but it is also necessary to put into a place a system of regular and planned maintenance" [4].

Maintenance contributes to the achievement of objectives of building construction which include building stability, weather tightness, internal comfort level, optimum use of the building, longer serviceable life [4]. Regular, planned and timely maintenance strategies should be put into practice immediately after the building has been constructed [4].

\section{G. Factors influencing maintenance:}

The factors influencing the maintenance of a building are as follows [4]:

\section{Cost:}

The direct cost for maintenance would contribute to 70 to $90 \%$ of the total cost which would be spent on material and labour [4].

\section{Building age:}

The maintenance practices should be implemented immediately after a building occupancy to obtain maximum life expectancy out of each building component as in time

The components wear out reducing the overall 
serviceability and the remaining functional life span [4].

\section{Availability of physical resources:}

The quality, quantity and presence of materials, components, services, equipment, labour etc. influence the maintenance of a building [4].

\section{Urgency of maintenance:}

Sometimes the repair services unless attended to immediately cause a lot of inconvenience to the building occupants [4].

\section{$5 . \quad$ Future use:}

The required maintenance should be carried in the context of future use such as expectation of changed occupancy and functional use [4].

\section{Social consideration:}

The implementation of maintenance repairs should be planned with a minimum level of disturbance in an occupied building as it would cause the temporary interruption of services [4].

\section{IV.BUILDING MATERIALS (FOR THE CASE STUDY)}

Among the various materials generally used in the construction of a building, the compositions of the ones which have been used in the identified building and in which the defects have been observed are as follows:

\section{A. Bricks:}

The composition of bricks used for construction may be made of burnt clay or mixture of sand and lime or of Portland cement concrete [5]. The clay used for the brick is composed of Silica (50 to 60\%), Alumina (20 to 30\%), Lime (10\%), Magnesia (<1\%), Ferric oxide $(<7 \%)$, Alkalis $(<$ $10 \%)$. In the manufacturing process, sometimes the additives such as fly ash, sandy loam, rice husk ash, basalt stone dust are also added [5].

\section{B. Wood:}

Wood is a hard, fibrous, polymeric material which forms a major part of the trunk branches of a tree [5]. The natural forms of wood include timber, lumber. Composite wood materials include plywood, fiberboards, chipboards, compressed wood, impregnated wood in which the natural wood material is a just a basic ingredient of a matrix or a laminate [5].

\section{Concrete:}

A composite man-made material consisting of rationally chosen mixture of binding material such as lime or cement, well graded fine and coarse aggregates, water and admixtures results in cement concrete [5].

\section{Paint:}

Paint can be termed as a liquid surface coat which on drying forms a thin film (60 to 150 microns) [5]. Oil paints, water paints, cement paints, bituminous paints, fire proof paints, luminous paints, chlorinated rubber paints are a few types of paints used in construction [5]. An oil paint is composed of a base (metallic oxide such as white lead, red lead, zinc white, aluminium powder, iron oxide, titanium white, antimony white, lithophone etc.), vehicle or binder (natural drying oils such as linseed oil, nut oil, poppy oil and tung oil), pigments (ground natural white chalk, mastics, grey graphite, dry yellow ochre, titanium dioxide, zinc

white, lead white, lithophone, chrome oxide, red lead, gas black soot aluminium powder, gold dust), solvents or thinners (petroleum, spirit, naptha and turpentine oil), driers or plasticizers (letharge, lead acetate, red lead, manganese dioxide and cobalt, zinc and lead chromate) and adultrants (barium sulphate, calcium carbonate, magnesium silicate and silica) [5].

\section{E. Metal:}

The metals used in the construction include iron, steel, aluminium, copper, lead, tin, zinc, nickel [5].

\section{F. Reinforced cement concrete (R.C.C):}

Reinforced cement concrete is formed using cement (lime/ordinary Portland cement/rapid hardening cement/high alumina cement), fine aggregates (natural river sand/finely crushed stone), coarse aggregates (broken stones), steel (mild steel 5 to $40 \mathrm{~mm}$ in diameter), clean water and sometimes admixtures (alum, aluminium sulphate, barium oxide, bitumen, calcium chloride etc.) [6].

\section{G. Glass:}

The types of glass manufactured are as soda - lime glass (mixture of sodium silicate and calcium silicate), potash - lime glass (potassium silicate and calcium silicate), potash - lead glass (mixture of potassium silicate and lead silicate), common glass (mixture of sodium silicate, calcium silicate and iron silicate) and borosilicate glass (70 to $80 \%$ silica, 7 to $13 \%$ boric oxide, smaller amounts of alkalis such as sodium and potassium oxides and aluminium oxide) [6].

\section{V.THE BUILDING DETAILS (CASE STUDY):}

\section{A. Introduction:}

A residential house in Sagar Nagar, Visakhapatnam [7], has been identified for the case study. The house is a perfect example of the condition that will be witnessed when maintenance is not done regularly for a building by the occupants. A duplex house, with greater percentage of open spaces in the site, was originally intended to be used as a weekend farm house. Over the years, the building has become prone to various factors leading to its current state. Hence, a study of its current condition would give us results that would be helpful in understanding the problems caused when the maintenance strategies are not followed.

\section{B. Location:}

The building is located in a residential area of Musalayya Palem, Sagar Nagar in Visakhapatnam. The coordinates of the site are $17^{\circ} 45^{\prime} 55.0^{\prime \prime} \mathrm{N} 83^{\circ} 21^{\prime} 44.9^{\prime \prime} \mathrm{E}$ [7].

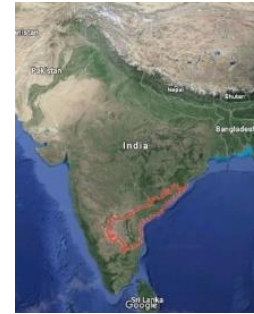

Figure 1 (a)

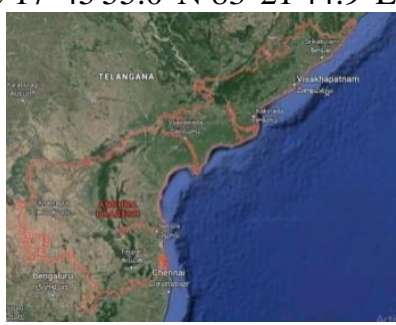

Figure 1 (b) 


\section{Deterioration of a Building through Environmental and Anthropological Causes}

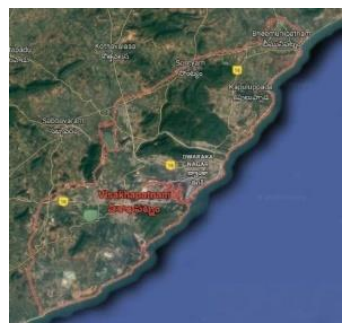

Figure 1 (c)
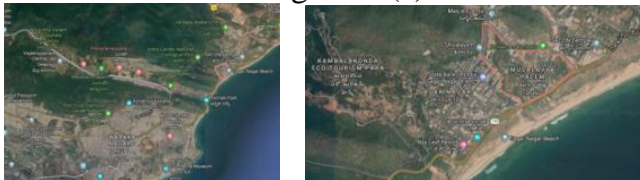

Figure 1 (d) Figure 1 (e)

Figure 1 - (a) Location of Andhra Pradesh in

India [7] (b) Location of Visakhapatnam city in the state of Andhra Pradesh [7] (c) Earmarked area of

Visakhapatnam city [7] (d) Earmarked area of Sagar

Nagar in Visakhapatnam city [7] (e) Earmarked area of Musalayya palem in Sagar Nagar, Visakhapatnam [7]

1. Distance from nearest landmarks:

The site [figure 2 (b)] is located at a distance of 210 meters North - East of Sagar Nagar entrance arch and the time of travel is approximately 1 minute [7]. It is located at a distance of $1.6 \mathrm{~km}$ south - west of ISKCON temple and the travel time is 4 minutes [7].

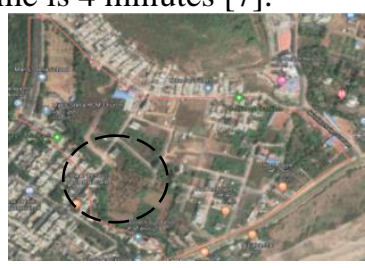

Figure 2 (a)

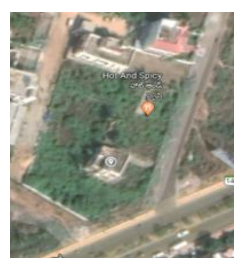

Figure 2 (b)
Figure 2 - (a) Overview of Musalayya palem neighborhood in Sagar Nagar, Visakhapatnam [7] (b) The building site in Musalayya palem neighborhood [7]

2. Distances for transportation:

The site is at a distance of $11.2 \mathrm{~km}$ North - East direction from the Visakhapatnam Railway Station and the travel time is 23 minutes [figure 3 (a)] [7].

From Visakhapatnam International Airport, it is $18.9 \mathrm{~km}$ North - East and it takes 41 minutes to reach the site [figure 3 (b)] [7].

From APSRTC Dwaraka Bus Station, the site is $9 \mathrm{~km}$ North - East and it takes 22 minutes to reach the place [figure 3 (c) ] [7].
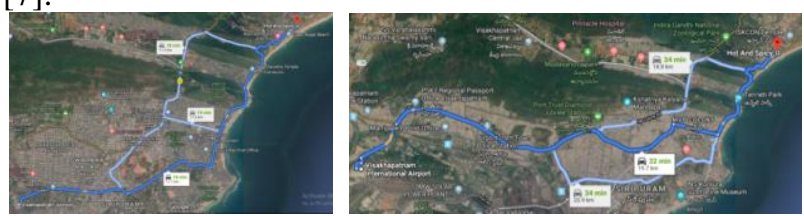

Figure 3 (a) Figure 3 (b)

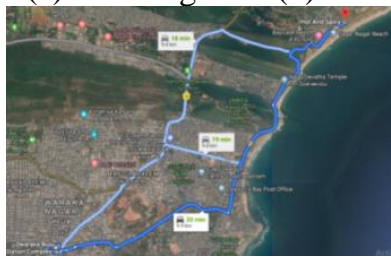

Figure 3 (c)

Figure 3 - (a) Distance of site from railway station [7] (b) Distance of site from Airport [7] (c) Distance of site from Dwaraka bus station [7]
C. Site Plan:

Table I: Site details of the building

\begin{tabular}{|l|l|}
\hline Detail/Area & Values/Dimensions/Details \\
\hline Site area & 12124.45 square feet (sft) \\
\hline Set Backs & $39^{\prime} 7^{\prime \prime}$ \\
\hline East & $10^{\prime} 0^{\prime \prime}$ \\
\hline West & $105^{\prime} 2^{\prime \prime}$ \\
\hline North & $19^{\prime} 0^{\prime \prime}$ \\
\hline South & $\begin{array}{l}40^{\prime} \text { '” wide road on the east, 150'0'” } \\
\text { wide road on the south }\end{array}$ \\
\hline Adjoining roads & 1194.25 square feet \\
\hline Building area & $9.8 \%$ \\
\hline $\begin{array}{l}\text { Percentage } \\
\text { built-up area }\end{array}$ & $90.2 \%$ \\
\hline $\begin{array}{l}\text { Percentage } \\
\text { open spaces }\end{array}$ & $30 \mathrm{~km} / \mathrm{h}$ West-South West winds \\
\hline Wind direction & Hot and humid \\
\hline Climate & Red sandy soil \\
\hline Topography &
\end{tabular}

D. Hatch Legend:

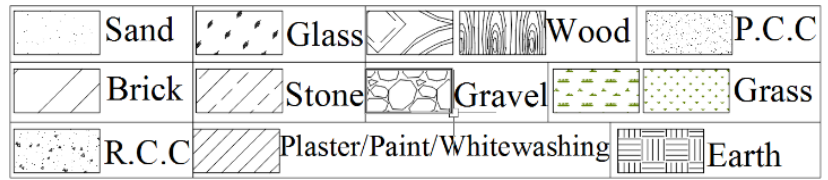

Figure 4 - Hatch of the materials used in the architectural drawings (Sheets 01, B01, B02, C01, C02, C03, W01, P01)

E. Floor Plans:

Table II: Room details at the different floor levels in the building

\begin{tabular}{|c|c|}
\hline Room/Detail & Value/Dimensions/Areas \\
\hline \multicolumn{2}{|l|}{$\begin{array}{l}\text { Ground Floor Level } \\
(+1 \text { ' 6") (GL) }\end{array}$} \\
\hline $\begin{array}{l}\text { GL } 1 \text { - Living (+ 6" } \\
\text { LVL) }\end{array}$ & $11^{\prime} \times 22^{\prime} 1.5^{\prime \prime}$ \\
\hline $\begin{array}{l}\text { GL } 2 \text { - Attached } \\
\text { Toilet }(+6 " \text { LVL) }\end{array}$ & $4^{\prime} 7.5^{\prime \prime} \times 10^{\prime}$ \\
\hline GL 3 - Dining & 11'3"'X 18'9" \\
\hline GL 4 - Kitchen & $11^{\prime} \times 7^{\prime}$ \\
\hline GL 5 - Puja & $12^{\prime} 1.5^{\prime \prime} \times 5{ }^{\prime}$ \\
\hline GL 6 - Bedroom & 11'X 14'3”' \\
\hline GL 7 - Attached toilet & $8^{\prime} 4.5^{\prime \prime} \times 5^{\prime}$ \\
\hline GL 8 - Stairs & 7'X 14'9”' \\
\hline \multicolumn{2}{|l|}{$\begin{array}{l}\text { First Floor Level (+ } \\
\text { 12' 6") (FL) }\end{array}$} \\
\hline FL 1 - Stairs & 7'X 14'9' \\
\hline FL 2 - Lounge & $11 ' 10.5$ "X 18'9"' \\
\hline FL 3-Bedroom & 11'X 14' 3'" \\
\hline FL 4 - Attached toilet & $9^{\prime} 10.5^{\prime \prime} \times 55^{\prime}$ \\
\hline FL 5 - Pantry & 11'9"X 7'9"' \\
\hline FL 6 - Bedroom & $11^{\prime} 3{ }^{\prime \prime} \times 16^{\prime}$ \\
\hline FL 7 - Attached toilet & 4'3"' X 10' \\
\hline FL 8 - Dressing area & 11'3"X 7'9" \\
\hline FL 9-Terrace & 11'3"X 6'9" \\
\hline FL 10 - Balcony & 24'3" X 2' 6" \\
\hline
\end{tabular}




\begin{tabular}{|l|l|}
\hline $\begin{array}{l}\text { Portico LVL (+ 10') } \\
\text { (PL) }\end{array}$ & \\
\hline $\begin{array}{l}\text { Flooring LVL } \\
\text { dimensions }\end{array}$ & $10^{\prime}$ X 22' 3' \\
\hline $\begin{array}{l}\text { Terrace Floor Level } \\
\text { (+ 23' 6”) }\end{array}$ & \\
\hline Flooring area & 901.77 square feet (sft) \\
\hline
\end{tabular}

Table III: Specifications of the materials used in the construction of the building

\begin{tabular}{|l|l|}
\hline Specifications & \\
\hline Concrete & M15 (1:2:4) \\
\hline Framed structure & \multicolumn{2}{|l|}{} \\
\hline Red brick & $\begin{array}{l}\text { 9” X 4.5” X 3" } \\
\text { masonry in 1:3 } \\
\text { mortar }\end{array}$ \\
\hline Internal Plastering & Rough ceiling \\
\hline
\end{tabular}

\begin{tabular}{|l|l|}
\hline & $\begin{array}{l}\text { plastering, smooth } \\
\text { wall plastering }\end{array}$ \\
\hline Internal Paint & Oil bound distemper \\
\hline External plastering & Rough plastering \\
\hline External paint & $\begin{array}{l}\text { Water based cement } \\
\text { paint }\end{array}$ \\
\hline Flooring & $\begin{array}{l}\text { Cast-in-situ (mosaic } \\
\text { flooring) }\end{array}$ \\
\hline Doors/windows & $\begin{array}{l}\text { Teak wood with } \\
\text { enamel paint finish }\end{array}$ \\
\hline Grills & $\begin{array}{l}\text { MS 12mm guard } \\
\text { bars (horizontal and } \\
\text { vertical) }\end{array}$ \\
\hline
\end{tabular}

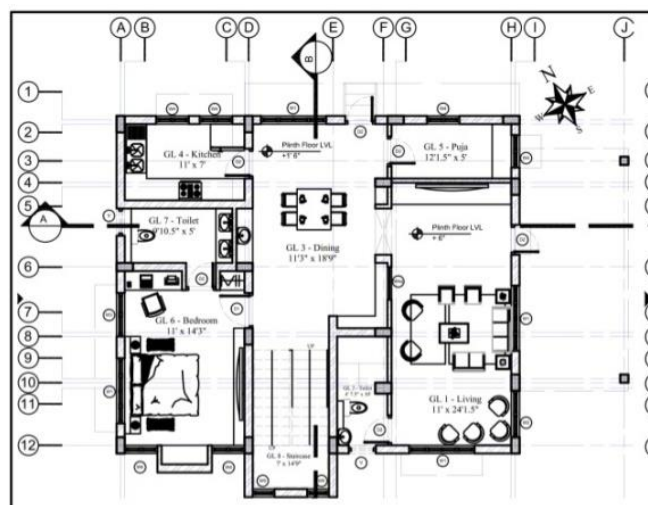

Ground Floor Plan
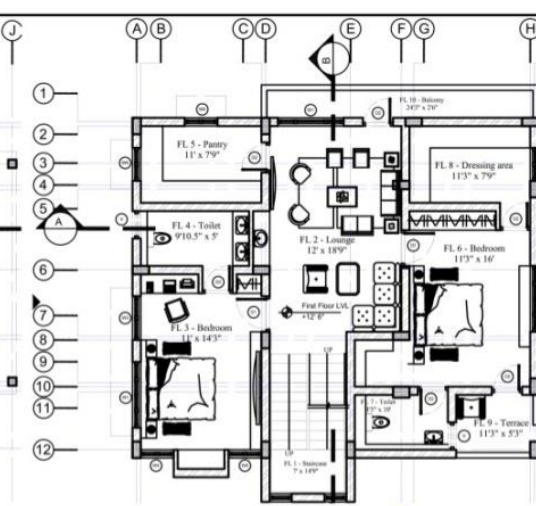

First Floor Plan
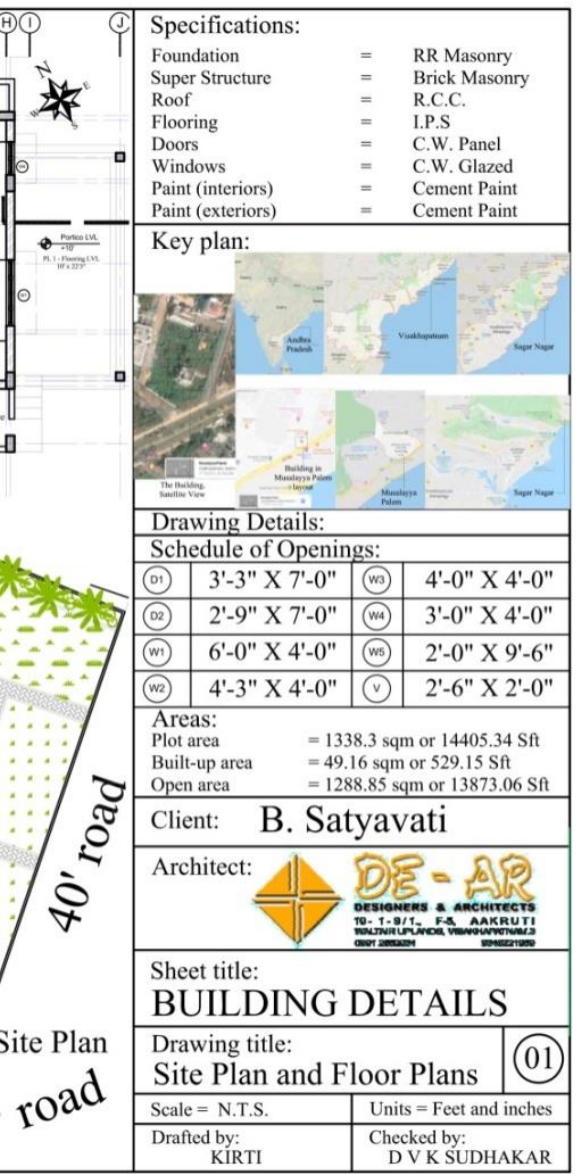

Figure 5 (a)

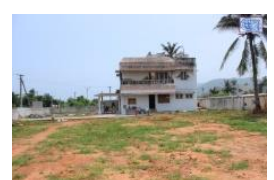

Figure 5 (b)

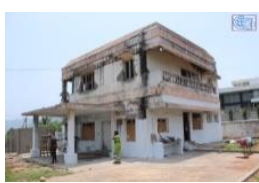

Figure 5 (c)

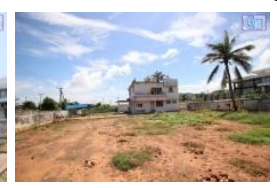

Figure 5 (d)
Figure 5 - (a) Sheet 01: Building drawings (site plan, ground floor plan, first floor plan, terrace plan with key location) of the case study (b) (c) (d) Views of the selected site and the building

\section{F. Post occupancy survey:}

The construction of the building was completed in November 1990. Immediately the building was occupied by the owners and was intended to use it as weekend farm house. The owners stayed in the house for a while and later

it was also rented for a brief period of time. The property was vacated by the tenants in the year 1995. Since then, the building has been completely abandoned.

Due to the non - occupancy of the building, regular maintenance of the building also has not been done since its abandonment. As a result, the building was vulnerable to various internal, natural, human, environmental factors resulting in its deterioration.

\section{G. Vulnerability factors:}

In totality, the building is vulnerable to factors such as internal, environmental, natural and human. Over the years, the life span of each of the material in the building was being consumed. 
Due to the lack of maintenance strategies put into practice, the attempt to repair and increase the life span of the materials was left undone. As a result, the process of deterioration has been developing within each of the material giving rise to various defects. These are the internal factors that contributed to the present condition of the building.

Being located on the coast, the site is much more prone to the environmental factors than usual [8]. These are the areas that act as the interface between the land and the sea that include zone of shallow water and area landward (beaches, cliffs and coastal dumes) [8]. The landward zones are affected to some extent by waves, tides, currents, humidity, sea breezes etc. [8]. Apart from it, the building was also exposed variations in climate over a long span of time i.e. heats during the summers, continuous rainfall during the rainy and cold during the winters. These are the environmental factors that played a part in its present condition.

The natural factors include disasters such as cyclones [9], [10]. The coast is vulnerable to high surges among the segments of the east coast [9]. Over the years Visakhapatnam city, has experienced 3 severe cyclones and 7 medium or normal cyclones [9]. The most severe damage due to cyclone is caused by Cyclone Hudhud which is the $2^{\text {nd }}$ strongest tropical cyclone within the North Indian Ocean that occurred on $12^{\text {th }}$ October 2014 [9]. It resulted in wind speeds of $175 \mathrm{~km} / \mathrm{h}$ (109mph) causing severe damages such as broken porticoes, parapets, balcony railings, and shattered windows to houses in Sagar Nagar, Visalakshi nagar and Kailasha hill base [9],[10].
Even though the building has not been occupied for more than a decade, yet there were a few visits made by the owners or the caretakers. These movements in the building have boosted the process of deterioration which was already in progress due to internal, environmental and external factors over the years. This can be termed as the human factor responsible for its current state.

\section{VI.THE STUDY}

\section{A. Introduction:}

A detailed inspection of the building is done through observations and the results are presented. There are a few locations where more than one type of defects have been identified and materials which contain more than one type of defect. During such instances, all the defects pertaining to one location have been explained together using proper nomenclature code allotted to each material and its defect. The nomenclature code is given to a defect based on its observation at different locations and not by the type of material defects categorized. Brick defects (BD), concrete defects (CD), metal or steel defects (SD), wood or timber defects (WD), glass defects (GD) and paint or plaster defects (PD) have been identified through their respective characteristic features and presented through architectural drawings (DWG) in architectural sheets (brick - B01, 02; concrete - C01, 02, 03; wood - W01; paint or plaster P01), photographs or images (figures). The methodology for identification of each material defect is shown below with the help of details of the components, characteristic features of the defects and inferences drawn from them.

Table IV: List of details shown in different sheets

\begin{tabular}{|c|c|c|c|c|c|c|c|}
\hline $\begin{array}{l}\text { S. } \\
\text { No }\end{array}$ & $\begin{array}{c}\text { Sheet } \\
\text { Num } \\
\text { ber }\end{array}$ & $\begin{array}{l}\text { Brick defects } \\
\text { (BD) }\end{array}$ & $\begin{array}{l}\text { Concrete Defects } \\
\text { (CD) }\end{array}$ & $\begin{array}{c}\text { Steel } \\
\text { Defects } \\
\text { (SD) }\end{array}$ & $\begin{array}{l}\text { Wood Defects } \\
\text { (WD) }\end{array}$ & $\begin{array}{c}\text { Glass } \\
\text { defects } \\
\text { (GD) }\end{array}$ & Paint Defects (PD) \\
\hline 1 & B01 & $\begin{array}{c}01,02,03,04,0 \\
5,06\end{array}$ & 06 & --- & $\begin{array}{ll}-- \\
\end{array}$ & 02 & $08,09,10,11,13,14,30$ \\
\hline 2 & B02 & $\begin{array}{c}07,07.2,08,09, \\
10,11\end{array}$ & $\begin{array}{ll}-- \\
\end{array}$ & --- & 06 & $\begin{array}{l}-- \\
\end{array}$ & 32 \\
\hline 3 & C01 & --- & $01,02,03,04$ & $01,02,03,04$ & 04 & 08,09 & $02,05,07,10,12$ \\
\hline 4 & $\mathrm{C} 02$ & --- & $05,06,08,11,13,15$ & 11 & 08 & $03,04,05$ & 16,24 \\
\hline 5 & C03 & --- & $\begin{array}{c}07,09,10,12,12.2,12 \\
.3,14,16\end{array}$ & $\begin{array}{c}07,08,09,09 \\
.2,10\end{array}$ & --- & --- & $\begin{array}{c}15,18,19,20,21,22,23 \\
25,26,28\end{array}$ \\
\hline 6 & W01 & --- & --- & --- & $\begin{array}{c}01,02,03,05,07,0 \\
9,10,11\end{array}$ & & --- \\
\hline 7 & P01 & --- & --- & $02,05,06$ & 11 & $\begin{array}{c}01,06,07,1 \\
0,11\end{array}$ & $\begin{array}{c}01,03 \\
04,06,17,27,28,29,31\end{array}$ \\
\hline
\end{tabular}

\section{B. Bricks:}

Bricks are used in internal and external walls, parapet walls, compound walls and landscaping edges. A total of 7 types of defects in number have been identified in bricks (BD 01 to 11) at 11 different locations. Based on the characteristic features of the defects observed, they have been categorized into the following types:
1.

Chemical reactions:

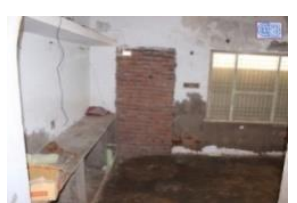

Figure 6 (a)

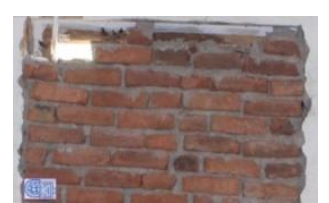

Figure 6 (b)
Figure 6 - (BD 01) GL 1: Living (a) View of covered entrance (b) Close up view of the exposed brick wall

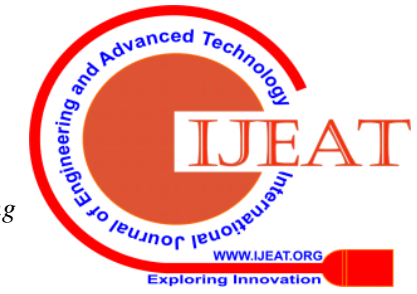


The defects caused due to chemical reactions are explained as follows:

Details:

Improper brick wall covering the entrance door D2 as it has been constructed at a later stage to cover the opening. Characteristic features:

Patches or dark spots [5] on the surface of the brick [figure 6 (BD 01)] and cracks at the brick junctions due to the use of freshly used bricks in masonry that lead to expansion in response to the moisture movement [4]. Inferences:

Application of plaster coats, white washing and paints on the surface of brick walls is necessary for its protection against the environmental factors.
2. Surface defects:

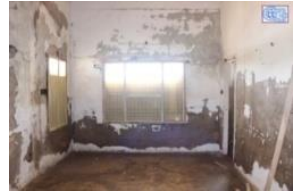

Figure 7 (a)

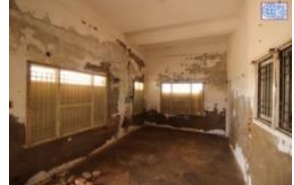

Figure 7 (b)
Figure 7 - (BD 02, PD 14) GL 1: Living (a) South wall view (b) View from North - West corner

Details:

Different time of construction of the wall [figure 9 (BD 04)] led to the difference in the coefficient of thermal expansion among its adjacent walls causing the development of cracks prone to the atmospheric agents.

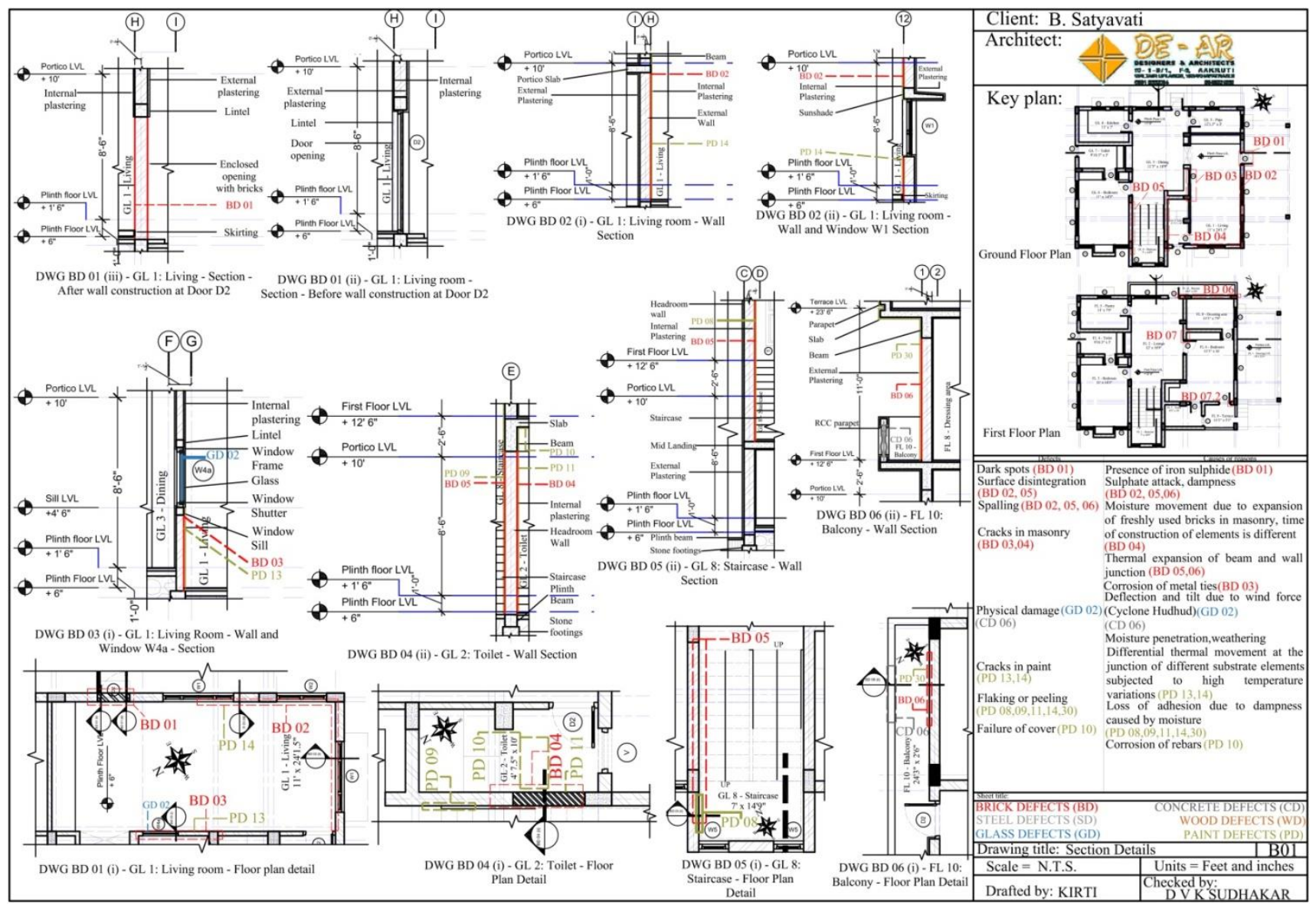

Figure 8 - Sheet B01: Architectural drawings of brick defects (BD) [4], [5], [10]

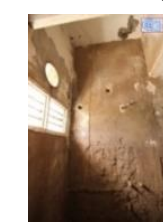

Figure 9 (a)

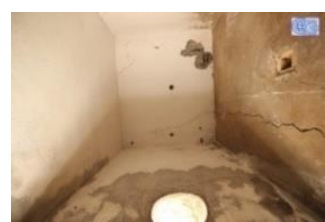

Figure 9 (b)

Figure 9 - (BD 04, PD 10, 11) GL 2: Toilet (a) West wall view (b) Slab view

Characteristic features:

Spalling and cracks in the brick wall [figure 9 (BD 02), figure 10 (BD 05), 11 (BD 06)] and the loss of paint coats. Inferences:

Application of fresh coats at regular intervals on the brick wall surface is required for its protection which when avoided causes flaking or peeling of paint surface

Published By:

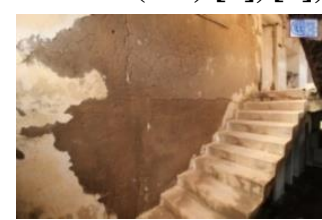

Figure 10

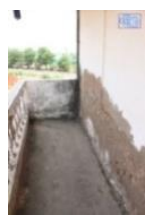

Figure 11
Figure 10 - (BD 05, PD 08) GL 8: Staircase wall - west view

Figure 11 - (BD 06, CD 06, PD 30) FL 10: Balcony south - East view 


\section{Deterioration of a Building through Environmental and Anthropological Causes}

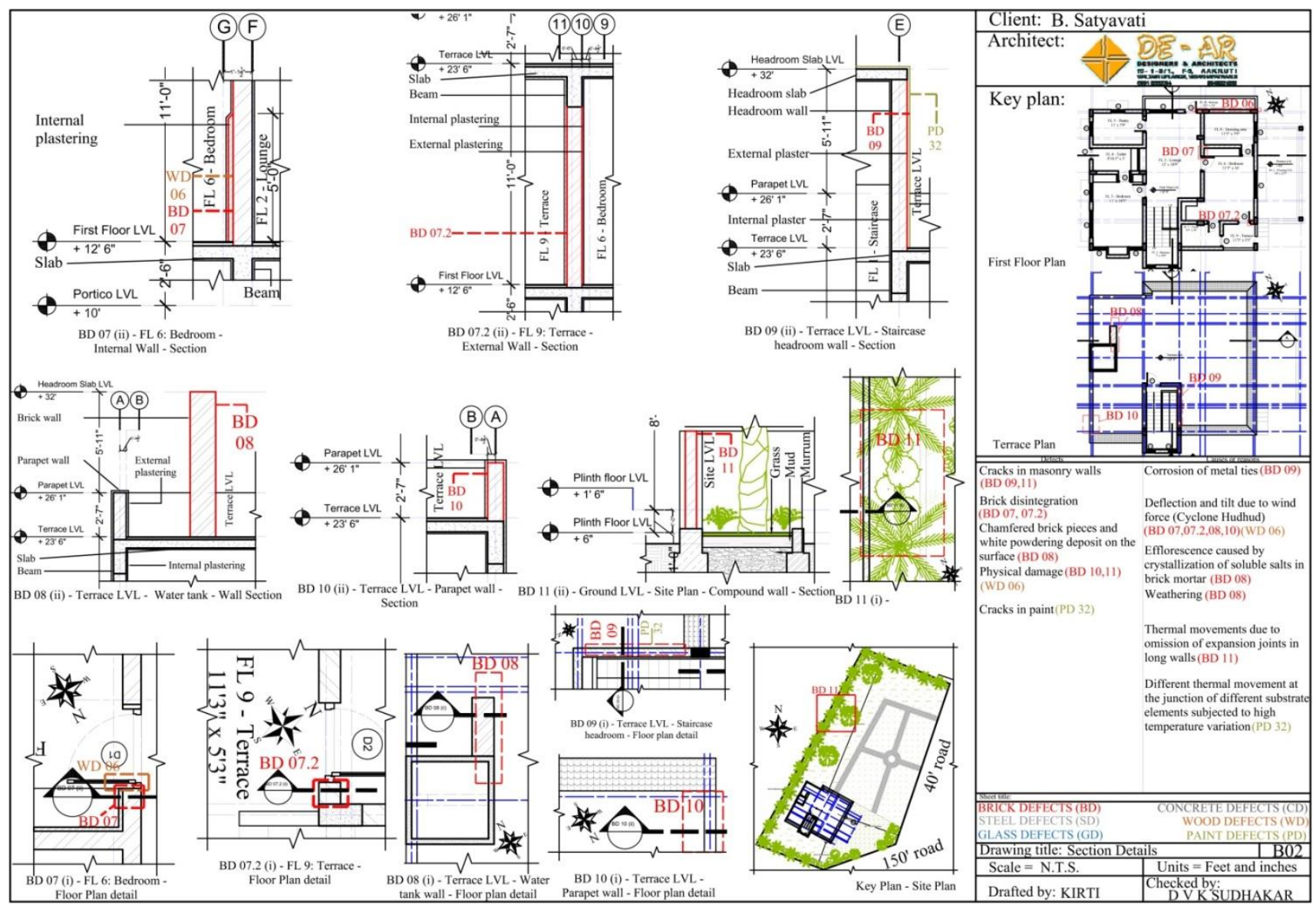

Figure 12 - Sheet B02: Architectural drawings of brick defects (BD) [4], [10]

Details:

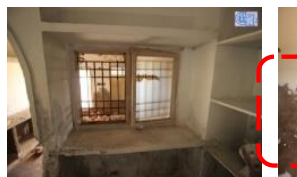

Figure 13 (a)

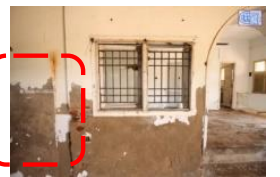

Figure 13 (b)

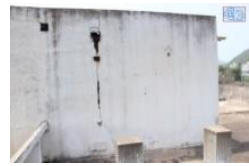

Figure 14
Figure 13 - (BD 03, GD 02, PD 13) Window W4a view from (a) GL 3: Dining - east view (b) GL 1: Living west view

Figure 14 - (BD 09, PD 32) Terrace level: Staircase headroom west wall view

Two materials are constructed together at a junction.

Characteristic features:

Difference in their coefficient of expansion and contraction has led to the cracks at the junctions [figure 13 (b) (BD 03), 14 (BD 09)] resulting in the corrosion of metal ties which further expands the cracks.

Inferences:

3. Physical damage:

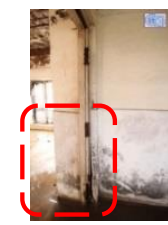

Figure 15

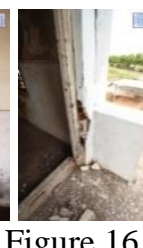

Figure 16

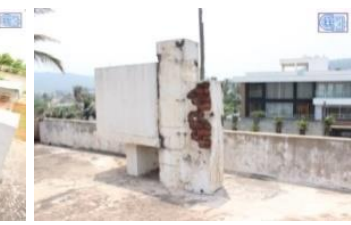

Figure 17
Figure 15 - (BD 07, WD 06) FL 6: Bedroom Door D1 North West corner view

Figure 16 - (BD 07.2) FL 9: Terrace Door D2 - north east view

Figure 17 - (BD 08) Terrace level: water tank - west view

Details:

The impact of after effects of a natural disaster (Cyclone Hudhud) [10]

Characteristic features:

Severe damage to the materials and due to their prior deterioration (figures 15, 16, 17, 18, 19)

Inferences:

The damage caused in unoccupied buildings is more compared to the functional ones because of their weak stability prior to the onset of a natural disaster [10].

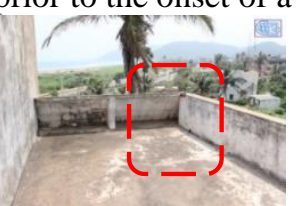

Figure 18

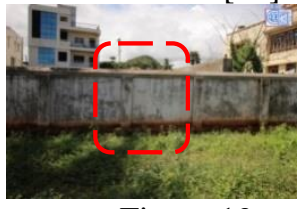

Figure 19
Figure 18 - (BD 10) Terrace level: Parapet wall - south west corner view

Figure 19 - (BD 11) Site level: Compound wall - west view

\section{Concrete:}

Reinforced cement concrete is used in foundations, columns, beams, slabs, sunshades, and staircase. A total of 16 defects in number have been identified in concrete (CD 01 to 16). Based on the architectural drawings, features of the defects observed they have been categorized into the following: 


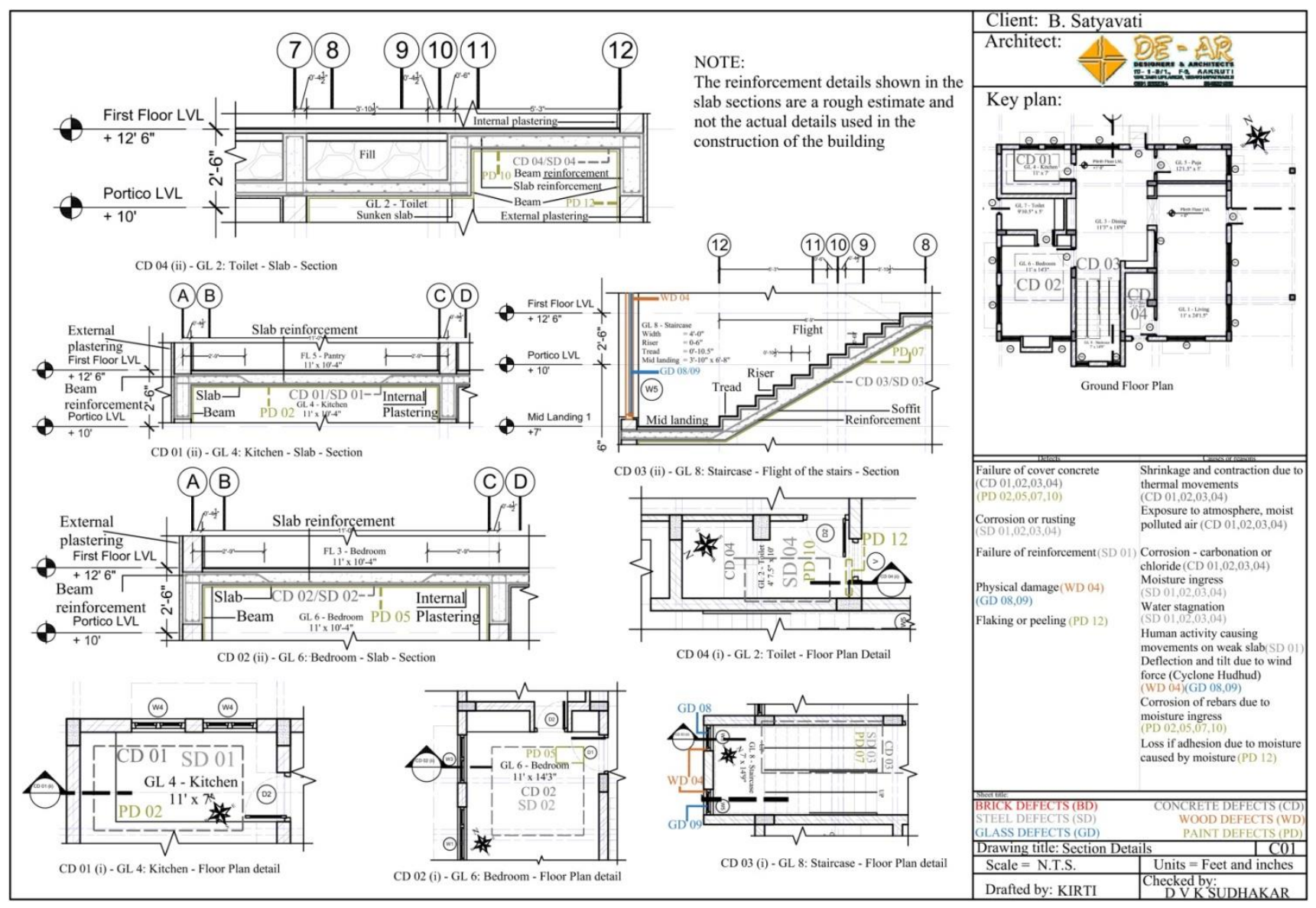

Figure 20 - Sheet C01: Architectural drawings of concrete defects (CD) [4], [10]

1. Surface disintegration:

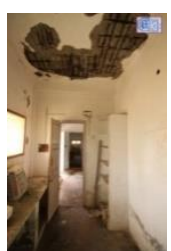

Figure 21 (a)

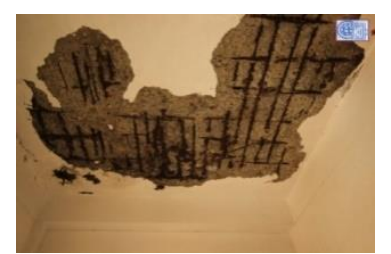

Figure 21 (b)
Figure 21 - (CD 01, SD 01, PD 02) GL 4: Kitchen (a) East view (b) Ceiling view

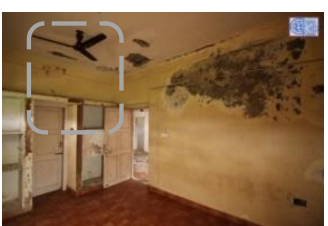

Figure 22 (a)

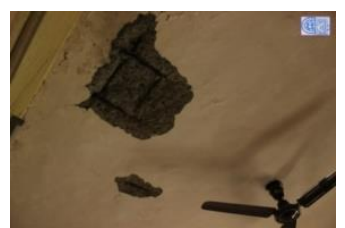

Figure 22 (b)
Figure 22 - (CD 02, SD 02, PD 05, PD 06) GL 6: Bedroom (a) North east view (b) Ceiling view
Details:

The defects in the components of a framed structure building would lead to the decrease in the stability resulting in its collapse after a brief period of time. Concrete slabs are the components that have been severely damaged.

Characteristic features:

The deterioration of the paint coats [figure 29 (b), 47, 49] and loss of concrete cover [figure 21 (b), 22 (b), 24 (b), 28 (b), 29 (b), 30 (c), 31, 32 (d)] are observed in most of the R.C.C components of the building. Inferences:

There were no measures taken to ensure the draining away of the rain water that penetrated the building through the staircase headroom open roof [10] and remained stagnated [figure 28 (a), (c), 30 (d)] for a long period of time thereby reacting with the materials. 


\section{Deterioration of a Building through Environmental and Anthropological Causes}

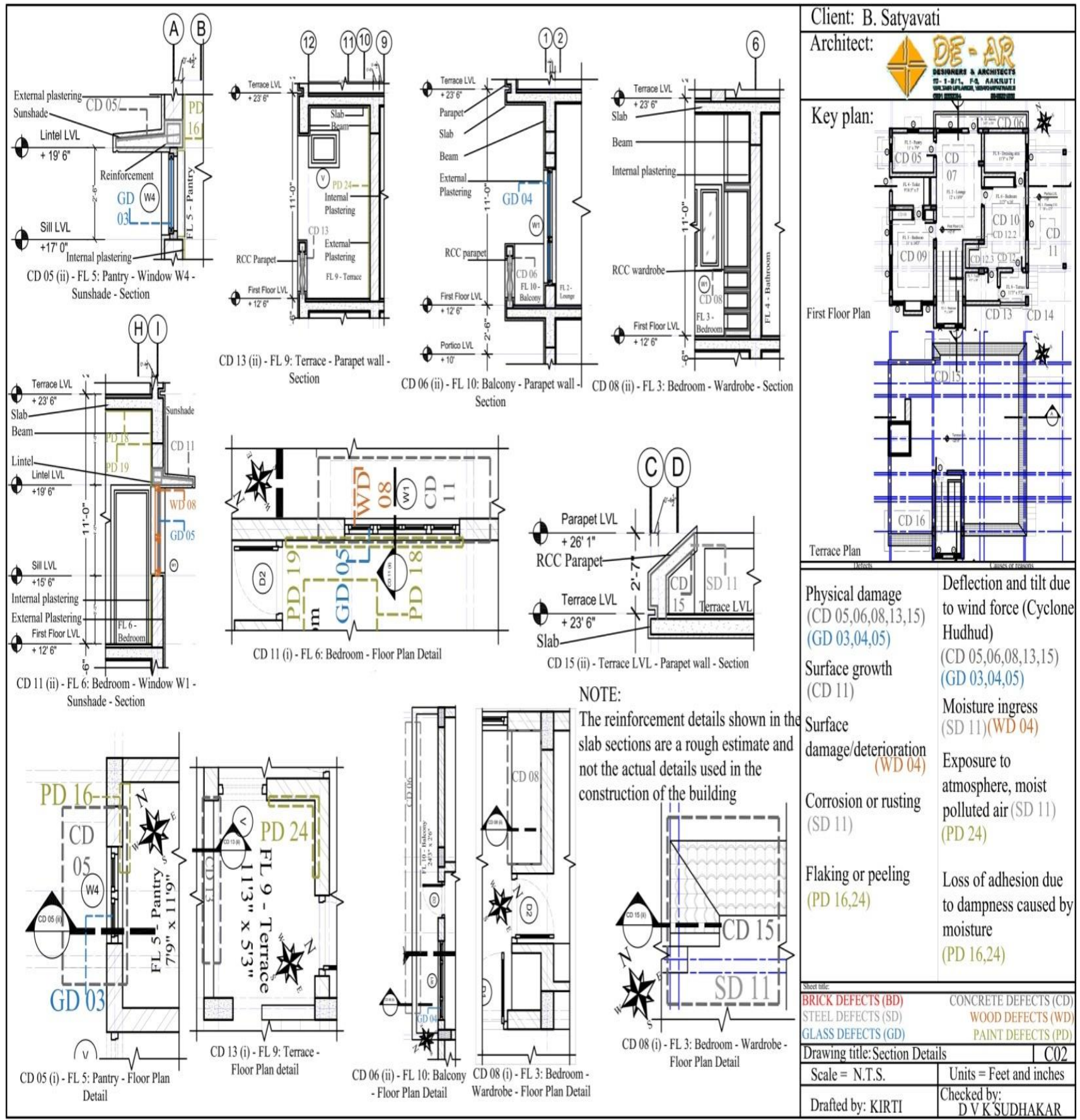

Figure 23 - Sheet C02: Architectural drawings of concrete defects (CD) [4], [5], [10]

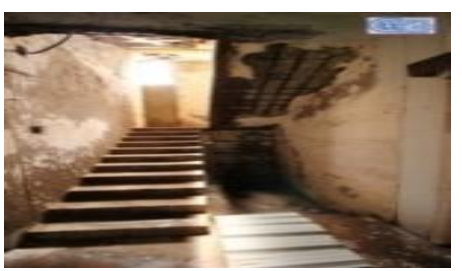

Figure 24 (a)

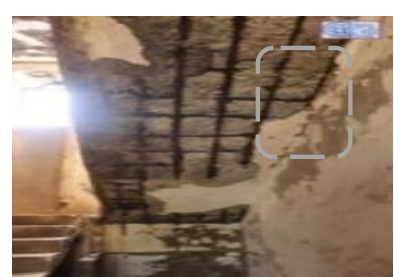

Figure 24 (b)

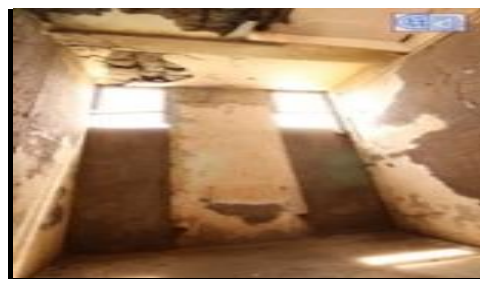

Figure 24 (c)

Figure 24 - (CD 03, SD 03, WD 04, GD 08, 09, PD 07) GL 8: Staircase (a) South view (b) Soffit view (c) South view of Windows W5 on mid landing

Retrieval Number: C6024029320/2020@BEIESP DOI: 10.35940/ijeat.C6024.029320

Journal Website: www.ijeat.org
Published By:

Blue Eyes Intelligence Engineering 2690 \& Sciences Publication 


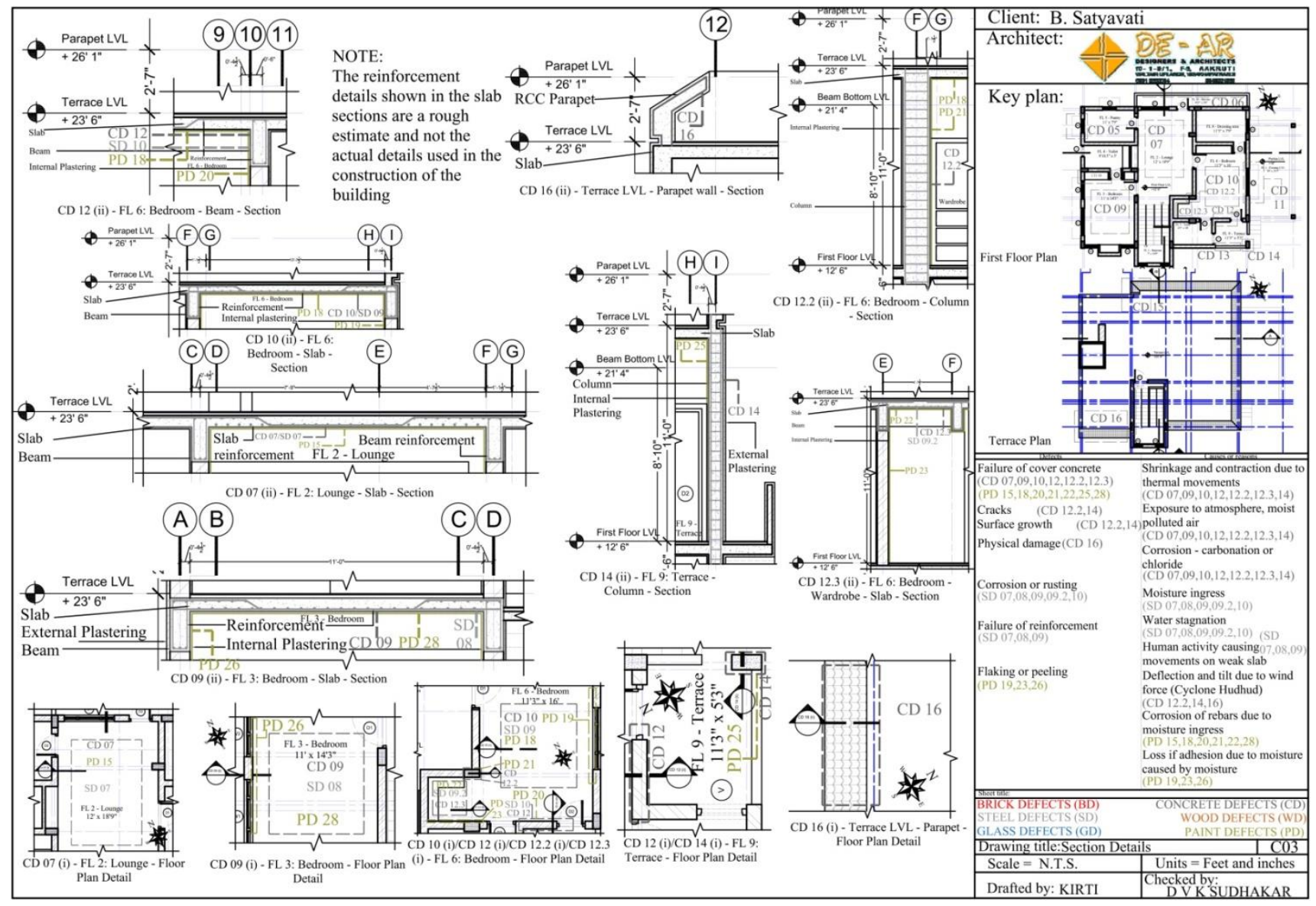

Figure 25 - Sheet C03: Architectural drawings of concrete defects (CD) [4], [10]

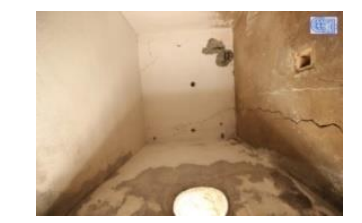

Figure 26

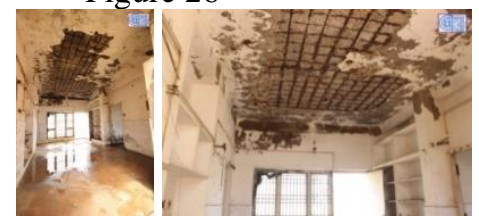

Figure 28 (a) Figure 28 (b) Ceiling view

Figure 27 - Terrace level - staircase headroom roof;

Figure 28 - (CD 07, SD 07, PD 15)FL 2: Lounge (a) North view (b) Ceiling view (c) Stagnant water on terrace level above the FL 2: Lounge

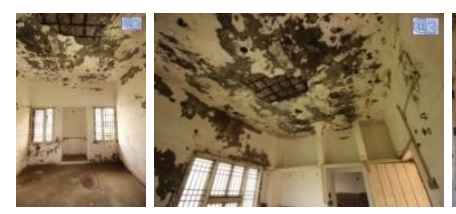

Figure 29 (a)

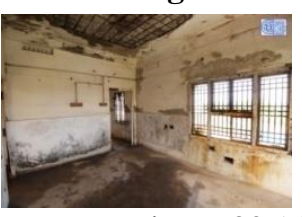

Figure 30 (a)
Figure 29 - (CD 08, SD 08, PD 26, 28)FL 3: Bedroom (a) South view (b) Ceiling view
Figure 26 - (CD 04, SD 04, PD 10, 12) GL 2: Toilet -

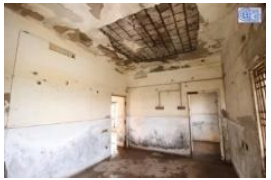

Figure 30 (b)

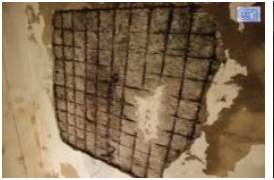

Figure 30 (c)

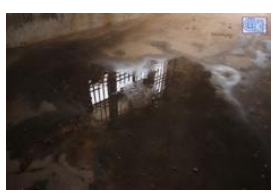

Figure 30 (d)
Figure 30 - (CD 10, SD 09, WD 08, GD 05, PD 18, 19)FL 6: Bedroom (a) North east view (b) North west view (c) Ceiling view (d) Floor level view showing the movement in water.

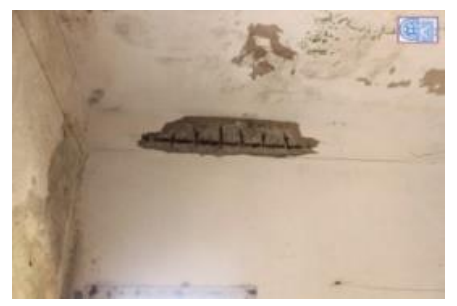

Figure 31 - (CD 12, SD 10, PD 20) FL 6: Bedroom Beam - South view

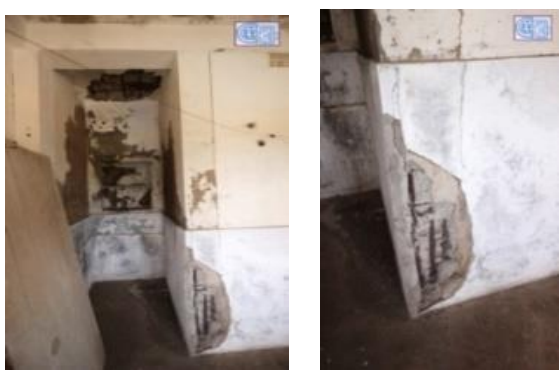

Figure 32 (a) Figure 32 (b)

Published By:

Retrieval Number: C6024029320/2020@BEIESP DOI: 10.35940/ijeat.C6024.029320

Blue Eyes Intelligence Engineering Journal Website: www.ijeat.org 


\section{Deterioration of a Building through Environmental and Anthropological Causes}

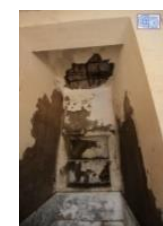

Figure 32 (c)

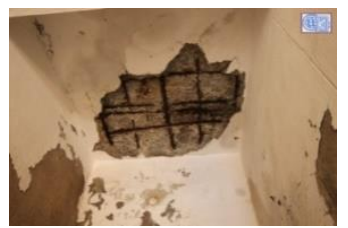

Figure $32(\mathrm{~d})$

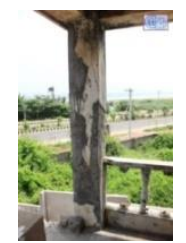

Figure 33
Figure 32 - (CD 12.3, SD 09.2, PD 22, 23) FL 6:

Bedroom, wardrobe area (a) West view (b) West view towards the column (c) West view (d) Ceiling view

Figure 33 - (CD 14, PD 25) FL 9: Terrace - Column South view

2.

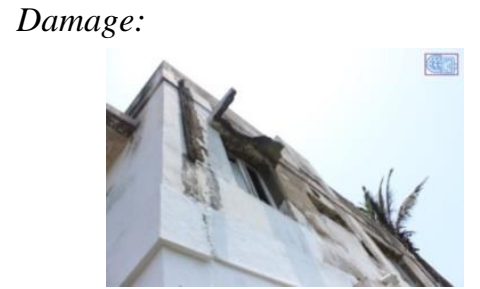

Figure 34 (a)
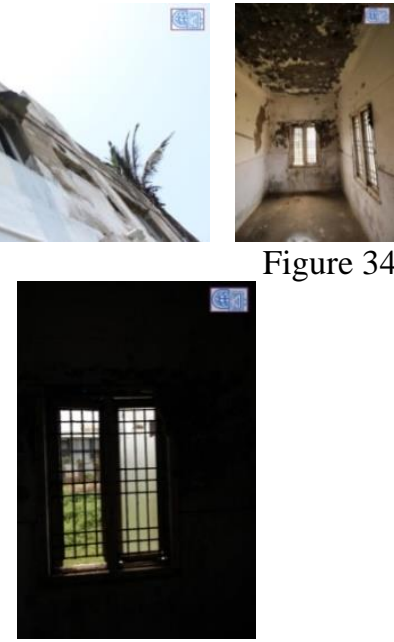

Figure 34 (b)

Figure 34 (c)

Figure 34 - (CD 05, SD 05, GD 03, PD 16, 17)FL 5:

Pantry (a) Window W4 view from the west facade (b) West view (c) Window W5 view towards the west

Details:

The after effects caused due to a natural disaster (Cyclone Hudhud) [10] similar to bricks.

Characteristic features:

Broken sunshades, wardrobes, precast parapet structures, terrace parapet walls observed in the building [figure 34 (a), 35 (a), (b), 36, 38 (a)]

Inferences:

The stages of deterioration spans from weakening of materials, development of cracks, impact of wind force, complete or partial damage to the structure [figure 35 (b) (b1) to (b5)]

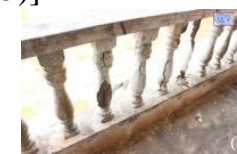

Figure 35 (a)

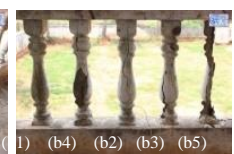

Figure 35 (b)

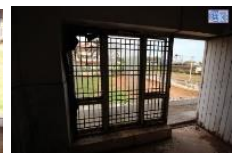

Figure 35 (c)
Figure 35 - (CD 06, GD 04) FL 10: Balcony (a) North east view (b) North view (c) Window W1 view from FL 2: Lounge

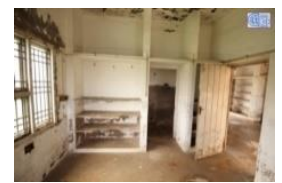

Figure 36 (a)

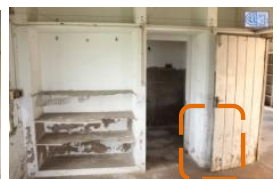

Figure 36 (b)
Figure 36 - (CD 08, WD 05)FL 3: Bedroom - Wardrobe

(a) North view (b) North close-up view

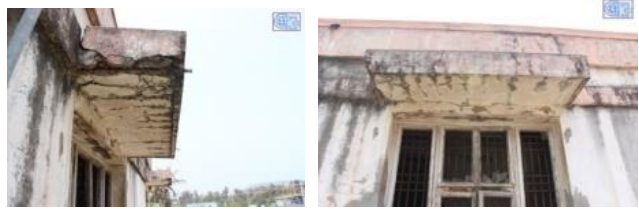

Figure 37 (a) Figure 37 (b)

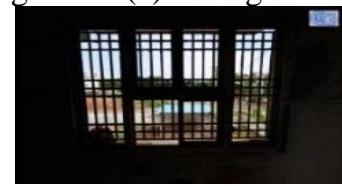

Figure 37 (c)

Figure 37 - (CD 11, WD 08, GD 05) FL 6: Bedroom

Window - W1 (a) Sunshade north view from FL 9:

Terrace (b) West view from Portico level (c) East view

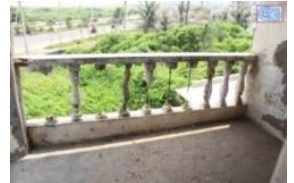

Figure 38 (a)

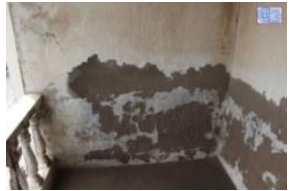

Figure 38 (b)
Figure 38 - (CD 13, PD 24) FL 9: Terrace (a) South view (b) North west corner view

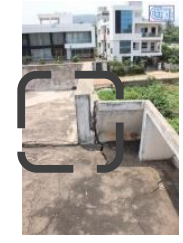

Figure 39

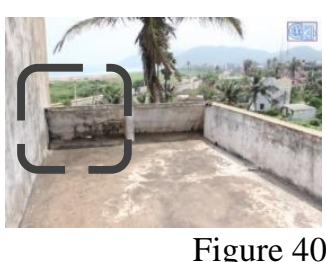

Figure 40
Figure 39 - (CD 15, SD 11) Terrace level - Parapet wall - North view

Figure 40 - (CD 16) Terrace level - Parapet wall - South west corner view

D. Metal or steel:

Details:

The metal used in the construction is steel. It is mostly used along with cement concrete as reinforcement in R.C.C. A total of 11 defects in number have been identified (SD 01 to 11 ). Recently there has been a human activity within the building for a brief period of time.

Characteristic features:

Severe corrosion of reinforcement due to the stagnant water and failure of reinforcement in some of the $1^{\text {st }}$ floor slabs due to increase in the rate of deterioration by the human activity.

Inferences:

Required measures are to be taken to ensure the drain of the water on the floor levels, water content within the slab and stability of the slab as continuation of human activity would lead to the collapse of the slab. 
E.

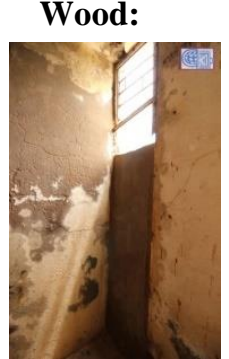

Figure 41 (a)

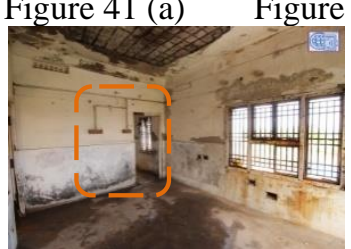

Figure 41 (d)

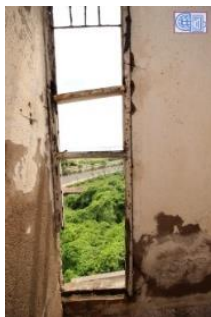

Figure 41 (b)

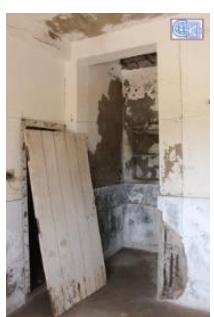

Figure 41 (c)

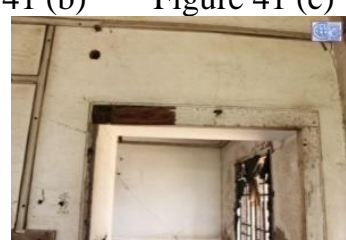

Figure 41 (e)

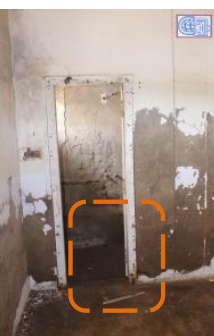

$41(\mathrm{f})$

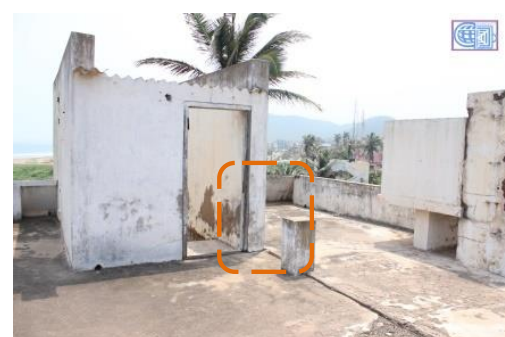

Figure 41 (g)

Figure 41 - (WD 03, 07, 09, 10) Wood defects (a) GL 8: Staircase - Window W5 - south east corner view (b) FL 1: Staircase - Window W5 - south view (c) FL 6:

Bedroom - Door D2 - south west corner view (d) FL 6: Bedroom - north east corner view (e) FL 6: Bedroom Door D2 - View (f) GL 1: Living - Door D2 - West view (g) Terrace level: Staircase headroom - Door D1 - South view

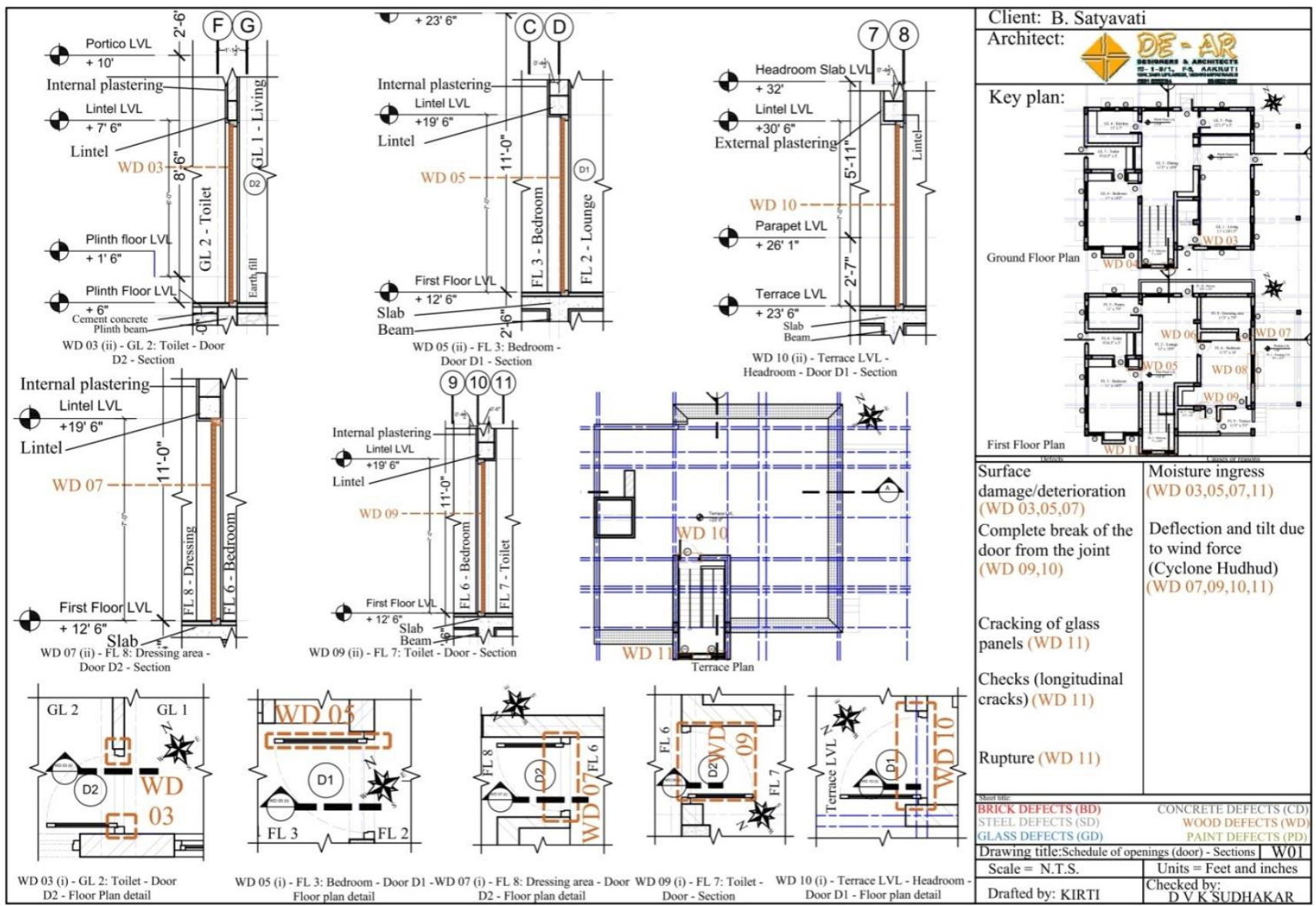

Figure 42 - Sheet W01: Architectural drawings of wood defects (WD) [4], [5], [10]

Details:

Wood is used for the frames and shutters of the doors and windows in the building. A total of 9 wood defects in number have been identified.

Characteristic features:

Distortion, surface damage [figure 36, 41 (d), (e)], rupture [figure 15, 16, 24 (c)], longitudinal cracks [figure 41 (a), (b), 50 (a), (b)] and cracking of glass panels [figure 41 (a), (b), 50 (a), (b)]

Inferences:

Wood has remained least affected among all the materials as the rate of degree of deterioration was very less. Only due to the physical damage [figure 41 (c)], the wood material became prone to remaining defects.

\section{F. Glass:}

Details:

Glass is used in the window openings of the building. A total of 11 defects (GD 01 to 11) in number have been observed which is damage due to natural disaster (Cyclone Hudhud) [10] similar to brick and concrete

Characteristic features:

Broken pieces of glass on the floor, shattered windows [figure 13, 24 (c), 34 (c), 35 (c), 37 (c), 44 (b), (c), 50 (a), (b)]

Inferences: 


\section{Deterioration of a Building through Environmental and Anthropological Causes}

No proper disaster resistant measures have been taken to ensure the safety from strong winds on glass within the building.

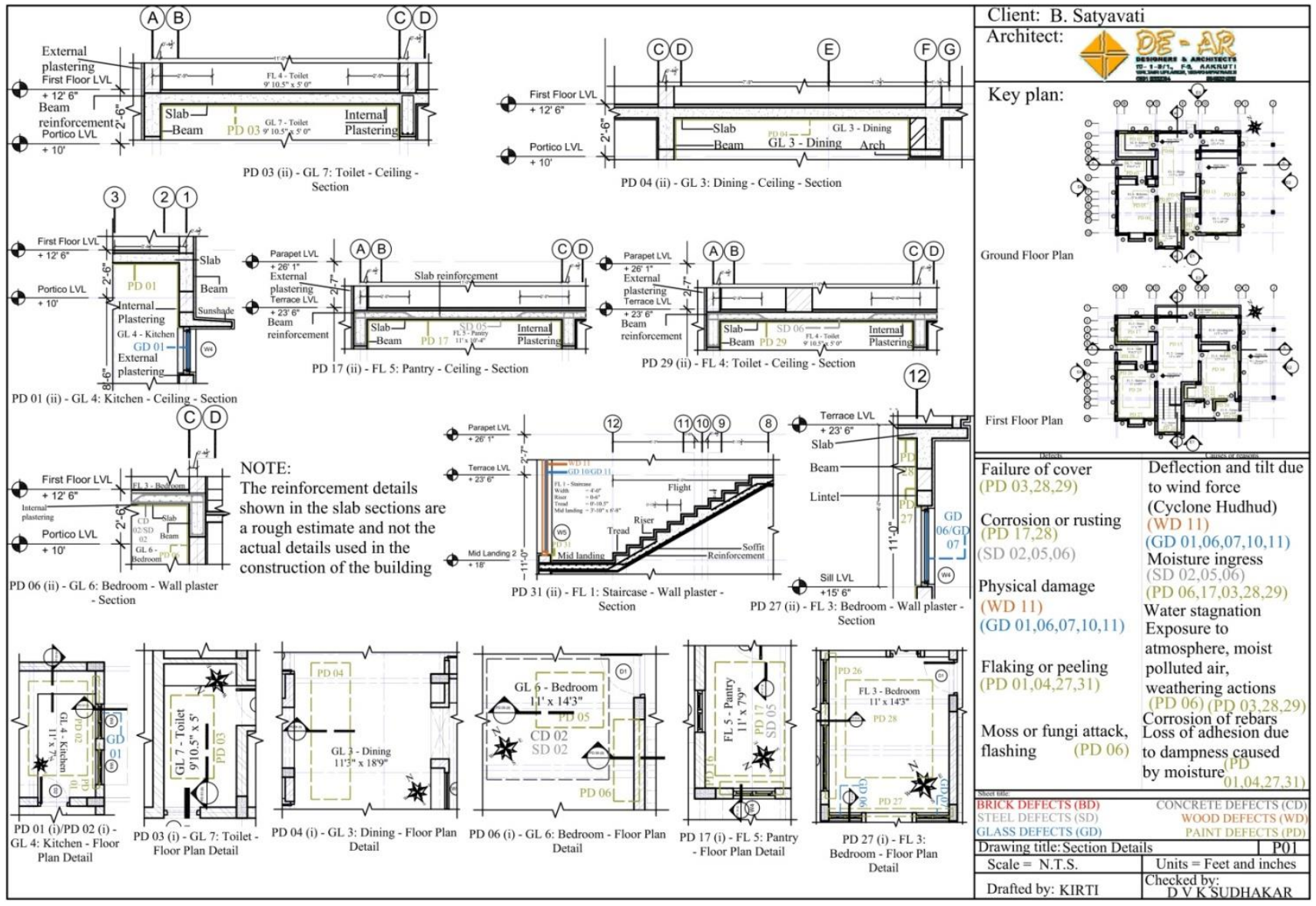

Figure 43 - Sheet P01: Architectural drawings of paint defects (PD) [4], [5], [10]

G. Paint:

1. Surface loss:

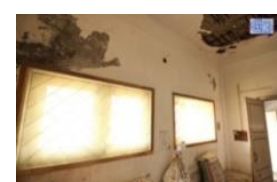

Figure 44 (a)

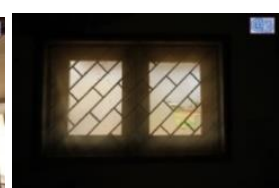

Figure 44 (b)

Figure 44 - (GD 01, PD 01) GL 4: Kitchen (a) North east corner view (b) Window W4 - North view
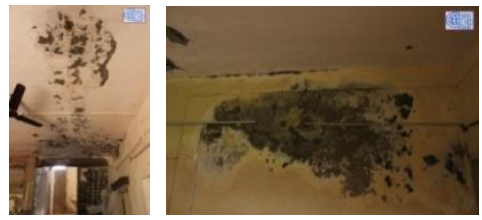

Figure 45

Figure 46

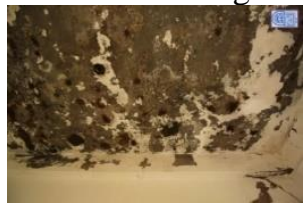

Figure 47

Figure 45 - (PD 04) GL 3: Dining - Ceiling view

Details:

A total of 32 defects (PD 01 to 32) in number have been observed but the types of defects in paints are 2 .

Figure 46 - (PD 06) GL 6: Bedroom - East wall view

Figure 47 - (PD 17) FL 5: Pantry - Ceiling view
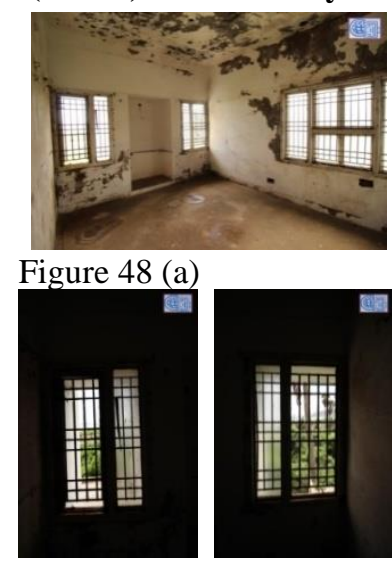

Figure 48 (b)

Figure 48 (c)

Figure 48 - (GD 06, 07, PD 26, 27, 28) FL 3: Bedroom (a) South west view (b) Window W4 - South east wall view

(c) Window W4 - South west wall view 
Characteristic features:

Loss of paint coats due to dampness, weathering actions, lack of regular maintenance, brown patches of red oxide on the surface due to corrosion of steel bars [figure 28 (b), 29 (b), 34 (b), 47, 49] and loss of coat cover due to corrosion [figure 51]

Inferences:

Re-plastering of the surfaces at regular intervals is to be done to ensure a good quality of paint against the climate. Alkali resistant paints should be used in coastal areas for better resistance against weathering [5]. Paint defects are observed within a short span of building functional life.

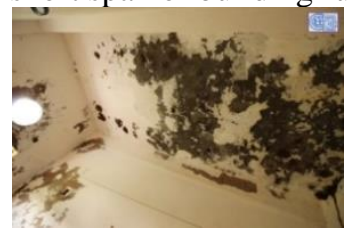

Figure 49

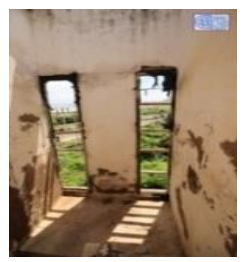

Figure 50 (a)

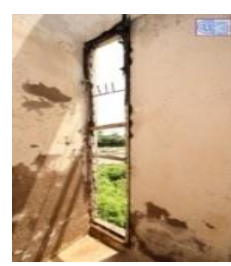

Figure 50 (b)
Figure 49 - (SD 06, PD 29) FL 4: Toilet - Ceiling view

Figure 50 - (WD 11, GD 10, 11, PD 31) FL 1: Staircase (a) South wall view from terrace level (b) South east corner view from mid - landing

2. Damage:

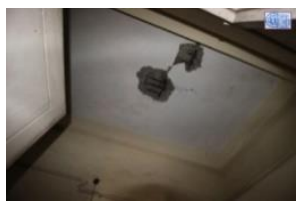

Figure 51 - (PD 03) GL 7: Toilet - Ceiling view

\section{VII.RESULTS AND ANALYSIS}

Table V: Overview of extent of damage as a result of case study

\begin{tabular}{|c|c|c|c|}
\hline $\begin{array}{c}\text { Type of } \\
\text { defect }\end{array}$ & Defect identified & Component code & $\begin{array}{c}\text { Frequency and degree of } \\
\text { deterioration }\end{array}$ \\
\hline \multirow[t]{5}{*}{$\begin{array}{l}\text { Chemical } \\
\text { reactions }\end{array}$} & Dark spots & BD 01 & Rare and minimal \\
\hline & Corrosion or rusting & $\begin{array}{c}\text { SD 01, 02, 03, 04, 05, 06, 07, 08, 09, 09.2, 10, 11, } \\
\text { PD 17, } 28\end{array}$ & Frequent and severe \\
\hline & $\begin{array}{l}\text { White powdering } \\
\text { deposit }\end{array}$ & BD 08 & Rare and minimal \\
\hline & Surface growth & CD 11, 12.2, 14 & Rare and optimum \\
\hline & Moss or fungi attack & PD 06 & Rare and optimum \\
\hline \multirow[t]{5}{*}{$\begin{array}{l}\text { Physical } \\
\text { damage }\end{array}$} & Failure of cover & $\begin{array}{c}\text { CD 01, 02, 03, 04, 07, 09, 10,12, 12.2, 12.3, PD } \\
02,03,05,07,10,15,18,20,21,22,25,28,29\end{array}$ & Frequent and severe \\
\hline & Disintegration & BD 07, 07.2, & Rare and severe \\
\hline & $\begin{array}{l}\text { Impact of an external } \\
\text { force }\end{array}$ & $\begin{array}{c}\text { BD 08, 10,11, WD, 04, 06, 09, 10, 11, CD 05, 06, } \\
\text { 08, 13, 15, 16, GD 01, 02, 03, 04, 05, 06, 07, 08, } \\
09,10,11\end{array}$ & Rare and severe \\
\hline & Failure of reinforcement & SD 01, 07, 08, 09 & Rare and severe \\
\hline & Break & WD 11 & Rare and severe \\
\hline \multirow[t]{5}{*}{$\begin{array}{c}\text { Surface } \\
\text { defects or } \\
\text { deterioration } \\
\end{array}$} & Spalling & $\mathrm{BD} 02,05,06$ & Frequent and optimum \\
\hline & Flaking or peeling & $\begin{array}{c}\text { PD 01, 04, 08, 09, 11, 12, 14, 16, 19, 23, 24, 26, 27, } \\
30,31\end{array}$ & Very frequent and severe \\
\hline & Cracks & CD 12.2, 14, BD 03, 04, 09, 11, PD 13, 14, 32 & Frequent and severe \\
\hline & Surface deterioration & BD 02, 05, WD 03, 04, 05, 07 & Frequent and severe \\
\hline & Longitudinal cracks & WD 11 & Rare and optimum \\
\hline
\end{tabular}

The study of the building results in the identification of defects observed in each of the materials. The defects and their causes have been specified for each of the selected components (BD 01 to 11, CD 01 to 16, SD 01 to 11, WD 01 to 11, GD 01 to 11 , PD 01 to 32 ) in their respective sheets (figures $8,12,20,23,25,42,43$ ). These results help in identifying the common defects, factors, reasons and areas which would be affected. Though the composition and nature of materials used for construction are different, the impact on each of them is inevitable. Based on the strength and quality the process of rate of deterioration begins in each of them. The table $\mathrm{V}$ presents the overview of defects and degree of damage in the building. Hence, the environmental causes such as weathering, coastal climate, natural disasters, and anthropological causes such as non- implementation of maintenance strategies, movement on weak structures, would ultimately lead to a progressive deterioration of a building over a long period of time.

\section{VIII.CONCLUSION}

In most of the construction projects, during the construction stages, the architect is responsible to coordinate, supervise, and correlate all the different aspects of a building. Even prior to the execution of the on-site work, architects and the team ensure a proper, longer, affordable environmental friendly, functional, sustainable building design from the design development stages. 
However, once the building is occupied, the responsibility of making the building environmental friendly and functional for a longer life span falls on to the occupants of the building. In the present scenario, there are examples of residential group housing, commercial buildings where the occupants ensure a proper functioning, maintenance and sustainability of their buildings. There are also examples where such practices are completely ignored by the occupants thereby leading to only the utilization of the building that would lead to its deterioration. Any such ignorance of practices would lead to the development of defects similar to the ones discussed in the above sections and in many cases, even more.

These aspects have been illustrated with the help of a case study of a building which has been exposed to environmental and anthropological factors. The building has witnessed different stages of deterioration over a long period of time. Despite the prolonged vulnerability and immense damage to various components of the building, there has been no change in its structural stability yet. If its exposure in the present condition continues for a while, then it will lead to the collapse of the building in a very short period of time. It is observed that mostly all the types of defects in the materials are chemical reactions, damage and surface deterioration in most of the building materials and areas. Such defects cause an immense negative impact on the site interactive spaces, aesthetics, functional time period, performance quality and capability, internal environment, human comfort levels, surrounding environment, stability of building, materials in the building, building form, historic or cultural features (if any), usage of spaces, emotions, security levels and so on. On the whole, it would greatly disturb the architecture of the building on a site level and neighborhood level.

The vulnerability factors responsible for defects and deterioration are similar in many regions and hence the study of such defects and its causes would be helpful in understanding the scale of damage and impact on environment by the occupants which would lead them to implement the maintenance strategies together at periodic intervals. The deteriorated buildings could be a threat to the environment if witnessed on a large scale such as ghost or abandoned towns. In case when a building is damaged through natural and anthropological causes, there are repair strategies which when implemented at the earliest by the owners or the occupants, would ensure the proper restoration and functioning of the building thereby decreasing the threat to the environment.

\section{ACKNOWLEDGEMENT}

Second Author would like to express his gratitude to Dr. V. Suresh, who allowed us with an open heart to study the building, Dr. Vidyasagar, who helped us get the permission for the case study, Prof. Dr. K. Mohan for his insights and suggestions on the topic.

First author would like to thank Associate Professor Allu Revathi Devi for her suggestions on the presentation of details, Assistant Professor Ravindra Patnayaka for his consistent guidance and inputs throughout the developing process, Assistant Professor Srikanth Panda for his insights regarding the aspects of climatology, Ar. B. Amrutha for her support and guidance in teaching the topic of defects in the subject of Building construction, batch: 2015 - 2020 students (Solinvictus) of Department of Architecture, Andhra University, for their presentations on the subject, Ar. Chandra Kishore, for sharing his knowledge and camera gear in the skills of photography.

\section{REFERENCES}

1. Alan Jefferis, David A. Madsen, David P. Madsen, "Architectural Drafting and Design", $6^{\text {th }}$ Edition, published by Delmar Cengage Leaming, Countries: Australia, Brazil, Japan, Korea, Mexico, Singapore, Spain, United Kingdom, United States, Year 2011, ch. 41 pg 935.

2. Suryakala Nannapaneni, Ravindra Patnayaka, "Digital Architecture Manifesting an accurate virtual built environment", International Journal of Research in Engineering and Technology, eISSN: 2319-1163; pISSN: 2321-7308, Volume: 05 Issue: 03, Mar16, Pg 169.

3. Post occupancy evaluation, Retrieved from Wikipedia: https://en.wikipedia.org/wiki/Post-occupancy_evaluation

4. P.S.Gahlot and Sanjay Sharma, "Building Repair and Maintenance Management", First Edition 2006 Reprint 2008, 2010, CBS Publishers and Distributors Pvt. Ltd, New Delhi, Bangalore, Pune, Chennai, Cochin, ch. 1 pg 5 to 9 , ch 3 pg 39 , ch 5 pg 85 to 119 .

5. S.K. Duggal, "Building Materials", Thirty ninth revised and enlarged edition, New Age International (P) Limited, Publishers, New Delhi, Bangalore, Chennai, Cochin, Guwahati, Hyderabad, Jalandhar, Kolkata, Lucknow, Mumbai, Ranchi, 2008, ch. 2 pg 14, 29, ch 4 pg 91, ch 10 pg 244, ch 13 pg 357, ch 14 pg 381, 383, 386, 387, ch 17 pg 421 to 424.

6. S.C.Rangwala, "Engineering Materials [Material Science]", $3^{\text {rd }}$ revised Edition, Charotar Publishing House Pvt. Ltd, Publishers of engineering text books, Gujarat, India, 2012, ch. 8 pg 153, ch 14 pg 305,307,308.

7. $17^{\circ} 45^{\prime} 55.0^{\prime \prime} \mathrm{N} 83^{\circ} 21^{\prime} 44.9^{\prime \prime} \mathrm{E}$,Retrieved from Google Maps:

8. https://www.google.com/maps/@17.7653164,83.362764,102 $\mathrm{m} / \mathrm{data}=$ !3m 1 ! $1 \mathrm{e} 3$

9. NERMN Beach Profile Monitoring 2011, Environmental Publication 2011/14, Pg 59.

10. Kolli Ramuje and B. Naga Malleswara Rao, "Hudhud Cyclone - A Severe Disaster in Visakhapatnam", International Journal of Research in Engineering and Technology, eISSN: 2319-1163 ; pISSN: 2321-7308, Volume: 03 Special Issue:16, ICPECDM - 2014, Dec-14, pg 157.

11. Mohan Kotamrazu, "Wind damage to buildings, Infrastructure and landscape elements along the beach road at

Visakhapatnam", International Journal of Research in Engineering and Technology, eISSN: 2319-1163 ; pISSN: 2321-7308,

Volume: 03 Special Issue:16, ICPECDM - 2014, Dec-14, pg 46.

\section{AUTHORS PROFILE}

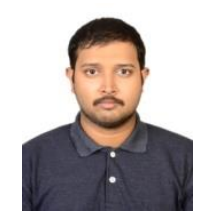

Kirti Chandra D., graduated in Bachelor of Architecture from School of Architecture, GITAM (Deemed to be University), Visakhapatnam. He worked as a guest faculty in Department of Architecture, Andhra University College of Engineering (A.U.C.E) and has been working on various architectural projects since 2 years. His main area of interests are practicing architecture, teaching of on-site applications in architectural schools, concepts of urban design and research in architecture.

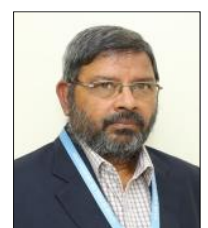

D. V. K. Sudhakar, is a practicing architect in Visakhapatnam and a senior professor (design chair) in School of Architecture, GITAM (deemed to be University). He has been a practicing architect for 28 years with expertise in architectural planning, detailing, furniture and graphic design on-site architectural works. He is also a member of Indian Institute of Architects, Visakhapatnam chapter. He deals with the subject of Architectural Design focusing on bridging the gap between theory in architecture and practice in architecture for the curriculum. 